\title{
A Comparative Study on the Various Blocking Layers for Performance Improvement of Dye-sensitized Solar Cells
}

\author{
Jong-Su Woo and Gun-Eik Jang ${ }^{+}$ \\ Department of Advanced Materials Engineering, Chungbuk National University, Cheongju 361-763, Korea
}

Received July 26, 2013; Revised July 31, 2013; Accepted October 16, 2013

In this study, short-circuit preventive layer (blocking layer) was deposited between conductive transparent electrode and porous $\mathrm{TiO}_{2}$ film in the DSSCs. As blocking layer, we selected the metal-oxide such as $\mathrm{TiO}_{2}, \mathrm{Nb}_{2} \mathrm{O}_{5}$ and $\mathrm{ZnO}$. The sheet resistance with each different blocking layers were $18 \Omega /$ sq. for the $\mathrm{TiO}_{2}, 10 \Omega /$ sq. for the $\mathrm{Nb}_{2} \mathrm{O}_{5}$ and $8 \Omega /$ sq. for the $\mathrm{ZnO}$, while the RMS (Root Mean Square) roughness value of DSSCs were $39.61 \mathrm{~nm}$ for the $\mathrm{TiO}_{2}, 41.84 \mathrm{~nm}$ for the $\mathrm{Nb}_{2} \mathrm{O}_{5}$ and $36.14 \mathrm{~nm}$ for the $\mathrm{ZnO}$ respectively. From the results of photocurrent-voltage curves, a sputtered $\mathrm{Nb}_{2} \mathrm{O}_{5}$ blocking layer showed higher performance on $2.64 \%$ of photo-electrochemical properties. The maximum of conversion efficiency which was achieved under 1 sun irradiation by depositing the blocking layer increased up to $0.56 \%$.

Keywords: Dye-sensitized solar cells, Blocking layer, $\mathrm{TiO}_{2}, \mathrm{Nb}_{2} \mathrm{O}_{5}, \mathrm{ZnO}$

\section{INTRODUCTION}

Dye-sensitized solar cells (DSSCs) are promising alternative to the conventional p-n junction solar cells [1], due to simple structure and process, low cost fabrication, transparency, color control, and applicability in the flexible DSSCs [2-4]. The DSSCs are composed of a dye-adsorbed nano-porous $\mathrm{TiO}_{2}$ layer on fluorine-doped tin oxide (FTO) electrode, redox electrolytes and the counter electrode [5].

To generate meaningful electrical power from DSSCs, the electrons need to pass four important interfaces of DSSCs: dye $/ \mathrm{TiO}_{2}$, $\mathrm{TiO}_{2} / \mathrm{FTO}$, electrolyte/counter electrode, and dye/electrolyte [6]. As the key component of DSSCs, the nano-porous $\mathrm{TiO}_{2}$ electrode shows high surface area, which enables both efficient electron injection and light harvesting [7].

However, it also provides abundant $\mathrm{TiO}_{2}$ surface sites (direct route) and bare FTO conducting sites (indirect route), where the photo injected electrons may recombine with I3- species in the

${ }^{\dagger}$ Author to whom all correspondence should be addressed: E-mail: gejang@chungbuk.ac.kr

Copyright $\odot 2013$ KIEEME. All rights reserved.

This is an open-access article distributed under the terms of the Creative Commons Attribution Non-Commercial
License (http://creativecommons.org/licenses/by-nc/3.0) which permits unrestricted noncommercial use, distribution, and reproduction in any medium, provided the original work is properly cited.
diction

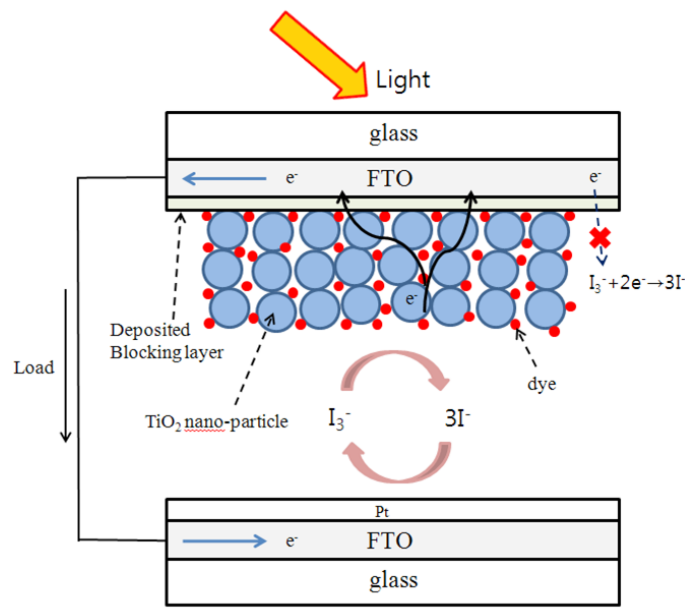

Fig. 1. Schematic view of interfaces in the DSSCs device.

redox electrolyte $\left(2 \mathrm{e}^{-}+\mathrm{I}_{3}^{-} \rightarrow 3 \mathrm{I}^{-}\right)[8-10]$.

The charge recombination mainly occurs at the electrode/ electrolyte interface due to the absence of energy barrier layer $[11,12]$. The recombination will cause the loss of the photocurrent. So the photovoltaic performance of DSSCs is seriously 
decreased [13]. Recently, the charge recombination can be significantly suppressed by employing a thin blocking layer $[14,15]$ as shown in Fig. 1. Semiconductors, such as $\mathrm{TiO}_{2}, \mathrm{Nb}_{2} \mathrm{O}_{5}$, $\mathrm{ZnO}$ and some insulating materials, such as $\mathrm{CaCO}_{3}$ and $\mathrm{BaCO}_{3}$, have been used as a blocking layer for the fabrication of DSSCs [1620].

In this work, we systematically investigated and compared the optical, structural, and photo- electrochemical properties based on different types of blocking layers such as $\mathrm{TiO}_{2}$, $\mathrm{Nb}_{2} \mathrm{O}_{5}$, and $\mathrm{ZnO}$. We expected that the electrodeposited various blocking layers $\left(\mathrm{TiO}_{2}, \mathrm{Nb}_{2} \mathrm{O}_{5}\right.$ and $\left.\mathrm{ZnO}\right)$ at the exposed $\mathrm{TiO}_{2} / \mathrm{FTO}$ interface contributes to the suppression of the charge recombination.

\section{EXPERIMENTS}

\subsection{Preparation of the standard DSSC}

The FTO glasses ( $7 \Omega /$ sq.) that we used were cleaned thoroughly in acetone and ethanol for $30 \mathrm{~min}$ in each step to remove the organic pollutants and other contamination [21]. After drying by $\mathrm{Ar}$ compressed gas, $\mathrm{TiO}_{2}$ nano-particle paste was coated on the FTO electrode by using the doctor-blade technique. And then $\mathrm{TiO}_{2}$ nano-porous film was annealed at $500^{\circ} \mathrm{C}$ for $30 \mathrm{~min}$ in air. The thickness of $\mathrm{TiO}_{2}$ film was approximately $14 \mu \mathrm{m}$. Ru complex dye (N719; 535 bis-TBA : cis-bis (isothiocyanato) and bis (2, 2'-bipyridyl-4, 4'-dicarboxylato) -ruthenium( II) bistetrabutylammonium $0.05 \mathrm{~g}$ in $100 \mathrm{ml}$ absolute ethanol (99.99\%)) was synthesized in advance. To adsorb a photo sensitized dye on the $\mathrm{TiO}_{2}$ surface the $\mathrm{TiO}_{2}$ working electrode was immersed in $\mathrm{Ru}$ complex dye (N719) for $24 \mathrm{~h}$ at room temperature. Immediately the dye-adsorbed $\mathrm{TiO}_{2}$ working electrode was rinsed with absolute ethanol and dried by Ar compressed gas. The counter electrode was prepared by sputtering (sputter coater; sc 7640) a pt layer on the other FTO coated glass electrode. The Pt-treated electrode was placed over the dye-coated electrode and edges of the cell were sealed with $0.5 \mathrm{~mm}$ wide strips of $60 \mu \mathrm{m}$-thick surlyn (solarnix, sx 1170, Hot Met). After sealing, an iodide based electrolyte of tri-iodide in acetonitrile (solarnix, AN-50) was injected into the cell through of the two small holes drilled in the counter electrode. The holes were then covered with small cover glass and sealed.

\subsection{Preparation of the added blocking layer $\left(\mathrm{TiO}_{2}\right.$, $\mathrm{Nb}_{2} \mathrm{O}_{5}$ and $\mathrm{ZnO}$ ) to DSSC}

As the blocking layer materials, $\mathrm{TiO}_{2}, \mathrm{Nb}_{2} \mathrm{O}_{5}$ and $\mathrm{ZnO}$ were selected in this study. The blocking layer was deposited between the FTO glass and $\mathrm{TiO}_{2}$ nano-porous film by using $\mathrm{RF}$ magnetron sputter. The $\mathrm{TiO}_{2}, \mathrm{Nb}_{2} \mathrm{O}_{5}$ and $\mathrm{ZnO}$ ceramic targets were fabricated (diameter; $2 \mathrm{inch}$ ) with high purity $\mathrm{TiO}_{2}(99.99 \%), \mathrm{Nb}_{2} \mathrm{O}_{5}(99.99 \%)$ and $\mathrm{ZnO}$ (99.99\%) powders respectively. More details about the sputtering conditions are given in Table 1.

The deposition conditions were maintained carefully stable during the growth of blocking layer. After that, those were fabricated in the same way as the standard DSSCs.

\subsection{Measurements}

The film thickness were measured using a surface profilier meter ( $\alpha$-step, TENCOR P-2). The crystal structure of the film was analyzed by $\mathrm{x}$-ray diffractometer (XRD; Rigku). The film morphology was observed by field emission scanning electron microscope (FE-SEM; JEOL). The electrical resistivity of the film was obtained using a four-point probe method. The Model name
Table 1. The fabrication of different blocking layers using RF magnetron sputtering method.

\begin{tabular}{cccc}
\hline Target & $\mathrm{TiO}_{2}$ & $\mathrm{ZnO}$ & $\mathrm{Nb}_{2} \mathrm{O}_{5}$ \\
\hline $\begin{array}{c}\text { electrode } \\
\text { temperature }\end{array}$ & $500^{\circ} \mathrm{C}$ & $500^{\circ} \mathrm{C}$ & $500{ }^{\circ} \mathrm{C}$ \\
\hline $\begin{array}{c}\text { target-electrode } \\
\text { distance }\end{array}$ & $55 \mathrm{~mm}$ & $55 \mathrm{~mm}$ & $55 \mathrm{~mm}$ \\
\hline $\begin{array}{c}\text { atmosphere } \\
\text { gas (Ar) }\end{array}$ & $50 \mathrm{sccm}$ & $50 \mathrm{sccm}$ & $50 \mathrm{sccm}$ \\
\hline base pressure & $1.4 \times 10^{-5} \mathrm{Torr}$ & $1.4 \times 10^{-5} \mathrm{Torr}$ & $1.4 \times 10^{-5} \mathrm{Torr}$ \\
\hline working pressure & $1.7 \times 10^{-2} \mathrm{Torr}$ & $1.7 \times 10^{-2} \mathrm{Torr}$ & $1.7 \times 10^{-2} \mathrm{Torr}$ \\
\hline RF power & $100 \mathrm{~W}$ & $100 \mathrm{~W}$ & $100 \mathrm{~W}$ \\
\hline
\end{tabular}
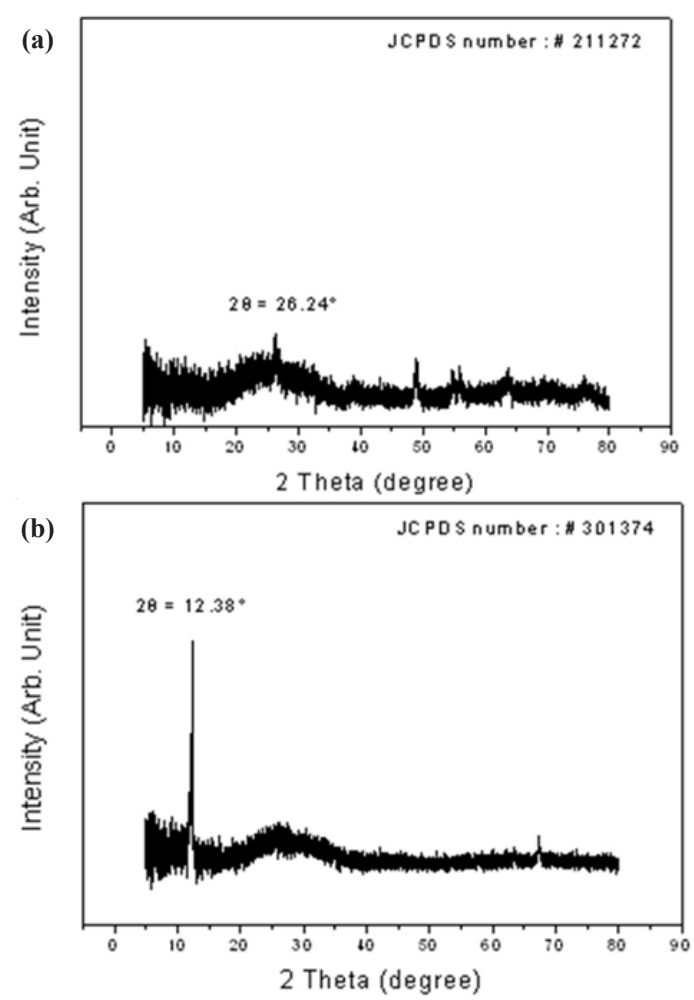

Fig. 2. XRD patterns of (a) $\mathrm{TiO}_{2}$ nano-porous film and (b) FTO electrode annealed at $500{ }^{\circ} \mathrm{C}$ electrode temperature.

of Nanoscope III a was used to perform atomic force microscopic (AFM) studies. The photocurrent-voltage (I-V) characteristics of the DSSCs were measured under AM 1.5, $100 \mathrm{~mW} / \mathrm{m}^{2}$ ( 1 sun) using a solar simulator.

\section{RESULTS AND DISCUSSION}

Figure 2 showed the XRD patterns of $\mathrm{TiO}_{2}$ nano-porous film and FTO electrode annealed at $500{ }^{\circ} \mathrm{C}$ electrode temperature.

In case of the Fig. 2(a), due to the background's peaks it seems like amorphous phase. But it clearly represented tendency of the crystallinity in $\mathrm{TiO}_{2}$ nano-porous film with (101) preferred orientation at $2 \theta=32.196^{\circ}$. The $\mathrm{TiO}_{2}$ nano-porous film exhibited $\mathrm{TiO}_{2}$ anatase crystalline phase. Fig. 2(b) showed XRD patterns of FTO electrode annealed at $500^{\circ} \mathrm{C}$ electrode temperature.

The FTO electrode showed the tendency of the crystallinity with (110) prefered orientation at $2 \theta=12.38^{\circ}$. It believed that the FTO electrode has excellent thermal stability because high temperature does not change the crystallity of FTO electrode. 

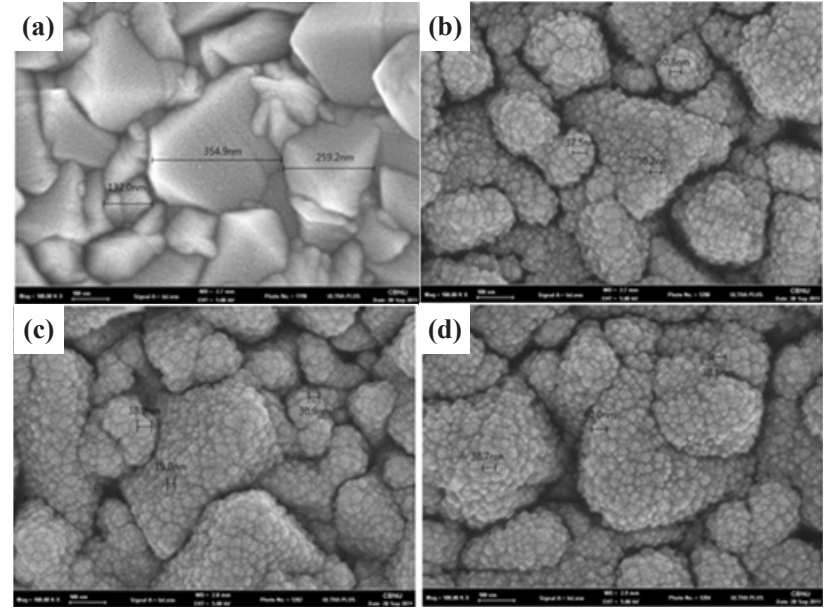

Fig. 3. Surface SEM images of (a) bare FTO electrode, (b) $\mathrm{TiO}_{2}$ deposited FTO selectrode, (c) $\mathrm{Nb}_{2} \mathrm{O}_{5}$ deposited FTO electrode, and (d) $\mathrm{ZnO}$ deposited FTO electrode.
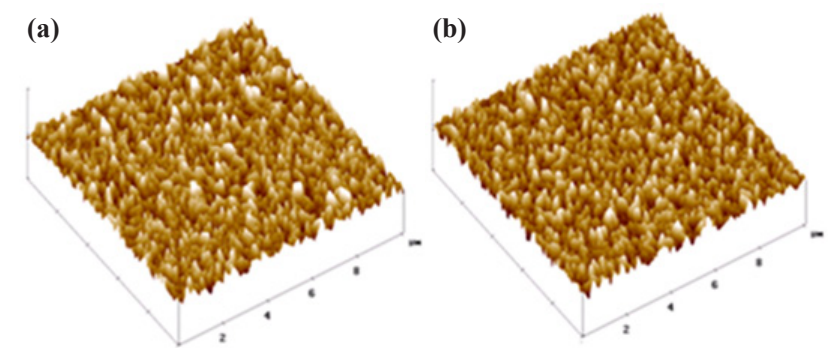

(c)

(d)
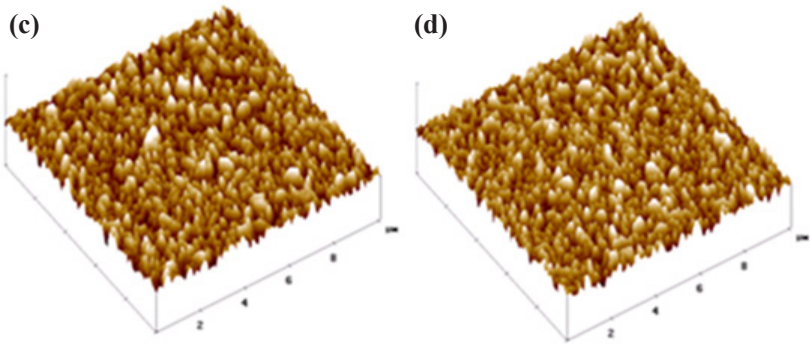

Fig. 4. Three-dimensional AFM images of (a) bare FTO electrode, (b) $\mathrm{TiO}_{2}$ deposited FTO electrode, (c) $\mathrm{Nb}_{2} \mathrm{O}_{5}$ deposited FTO electrode, and (d) $\mathrm{ZnO}$ deposited FTO electrode.

From the XRD results, it is clear that the structure of the fim such as $\mathrm{TiO}_{2}$ nano-porous film and FTO electrode are completely crystalline phase by annealing at $500^{\circ} \mathrm{C}$.

Figure 3 and Fig. 4 showed the FE-SEM and AFM images of bare FTO and sputtered blocking layers such as $\mathrm{TiO}_{2}, \mathrm{Nb}_{2} \mathrm{O}_{5}$ and $\mathrm{ZnO}$ on the FTO glass.

From the AFM images, it is clear that the sputtered blocking layers have smooth surface with RMS roughness value which decreased by $\sim 7 \mathrm{~nm}$.

The surface roughness is one of the important factors that determined optical properties. The thin film with flat and low surface roughness value shows a low reflectivity because the constructive interference and destructive interference are clearer according to the thickness.

From FE-SEM images, bare FTO showed the texture surface morphology which has diameter above $1 \mu \mathrm{m}$. In case of blocking layers deposited FTO electrodes in Fig. 3(b), Fig. 3(c) and Fig. $3(d)$ showed that $\mathrm{TiO}_{2}, \mathrm{Nb}_{2} \mathrm{O}_{5}$ and $\mathrm{ZnO}$ nano-particles were covered on the FTO electrode respectively. It is clear that the block-
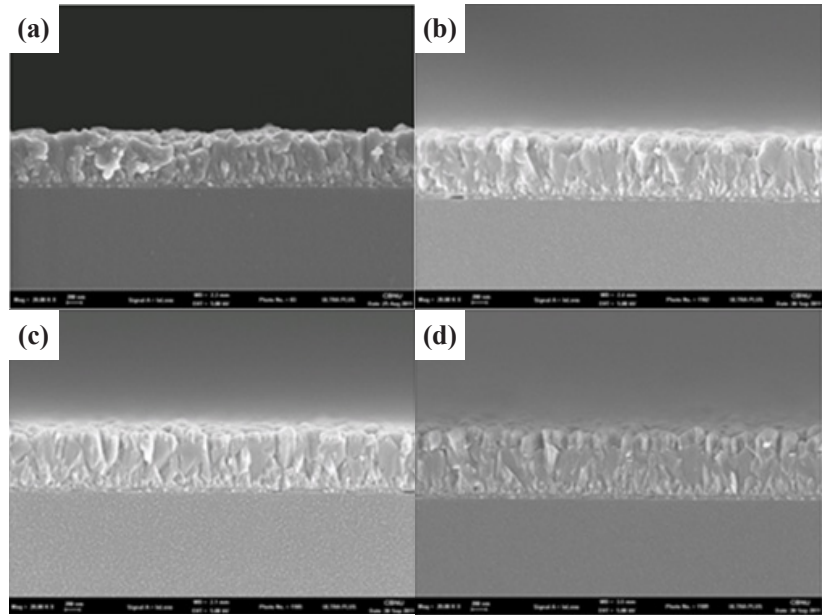

Fig. 5. Cross sectional SEM images of (a) bare FTO electrode, (b) $\mathrm{TiO}_{2}$ deposited FTO electrode, (c) $\mathrm{Nb}_{2} \mathrm{O}_{5}$ deposited FTO electrode, and (d) $\mathrm{ZnO}$ deposited FTO electrode.

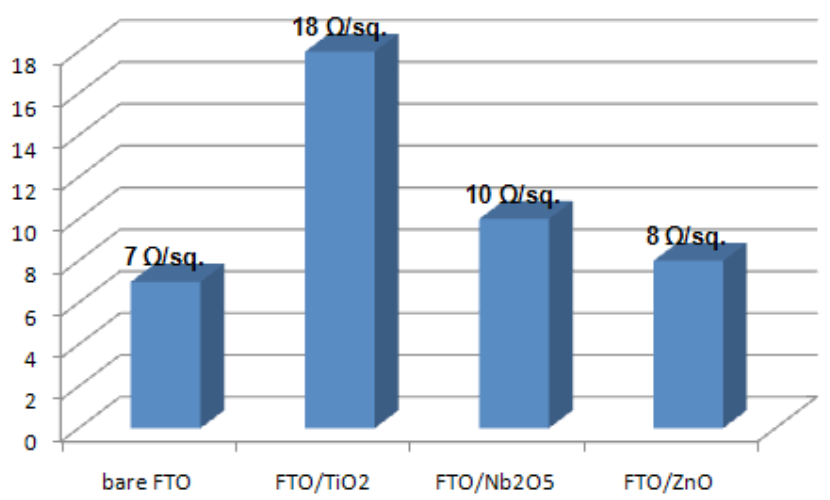

Fig. 6. Sheet resistance of (a) bare FTO electrode, (b) $\mathrm{TiO}_{2}$ deposited FTO electrode, (c) $\mathrm{Nb}_{2} \mathrm{O}_{5}$ deposited FTO electrode, and (d) $\mathrm{ZnO}$ deposited FTO electrode.

ing layers which have diameter up to $40 \mathrm{~nm}$ were deposited on FTO glass.

Figure 5 showed the cross sectional SEM images of bare FTO and various blocking layer deposited FTO electrodes. As the thickness of the $\mathrm{TiO}_{2}$ nano-porous film is above $14 \mu \mathrm{m}$, the images was not shown the material interface clearly. However, before sputtering the blocking layers, we calculated the deposition rate under the same condition. So, we are confident that the thickness of blocking layers are deposited approximately $50 \mathrm{~nm}$ even if the SEM images does not shown the thickness clearly. And also, in case of FE-SEM images in Fig. 3, it is clear that the difference from bare FTO was seen. It means that the blocking layers were deposited on FTO glass. It could be confirmed that $\mathrm{TiO}_{2}, \mathrm{Nb}_{2} \mathrm{O}_{5}$ and $\mathrm{ZnO}$ blocking layers are approximately $50 \mathrm{~nm}$ respectively.

Figure 6 showed the sheet resistance of bare FTO electrode and blocking layers of $\mathrm{TiO}_{2}, \mathrm{Nb}_{2} \mathrm{O}_{5}$ and $\mathrm{ZnO}$ sputtered on FTO electrode.

The sheet resistance of bare FTO electrode was about $7 \Omega /$ sq. However, after deposited the blocking layers on FTO electrodes, the sheet resistances were obtained such as $\mathrm{FTO} / \mathrm{TiO}_{2}=18 \Omega /$ sq., $\mathrm{FTO} / \mathrm{Nb}_{2} \mathrm{O}_{5}=10 \Omega /$ sq., FTO $/ \mathrm{ZnO}=8 \Omega /$ sq. respectively.

Especially, the most increased value of sheet resistance was obtained from $\mathrm{TiO}_{2}$ deposited FTO electrode. These results, we 
expected that the $\mathrm{TiO}_{2}$ deposited FTO electrode will negatively affect the current density $\left(\mathrm{J}_{\mathrm{sc}}\right)$ and the conversion efficiency $(\eta)$.

Figure 7 showed the photocurrent density-voltage (J-V) curves obtained under $100 \mathrm{~mW} / \mathrm{m}^{2}$ illumination with AM 1.5 conditions of DSSCs consisting of $\mathrm{TiO}_{2}$ electrode without and with blocking layer of $\mathrm{TiO}_{2}, \mathrm{Nb}_{2} \mathrm{O}_{5}$ and $\mathrm{ZnO}$.

The characteristic parameters for DSSCs can be obtained from the photocurrent density-voltage curve, such as the short circuit current $\left(J_{s c}\right)$, the open circuit voltage $\left(V_{o c}\right)$, fill factor $(F F)$ and conversion efficiency $(\eta)$.

The efficiency $\eta$ of the DSSCs can be calculated from the following equation;

$$
\eta=\mathrm{J}_{\mathrm{sc}} \mathrm{V}_{\mathrm{oc}} \mathrm{FF} / \mathrm{Pin}
$$

where, $\mathrm{J}_{\mathrm{sc}}$ is the integral photocurrent density(current obtained at short circuit conditions divided by the area of the cell), $\mathrm{V}_{\mathrm{oc}}$ is the open circuit voltage, $\mathrm{FF}$ is the fill factor, $\mathrm{FF}=(\mathrm{I} \times \mathrm{V}) \mathrm{max} / \mathrm{I}_{\mathrm{sc}} \mathrm{V}_{\mathrm{oc}}$ (related to the serious resistance for a potential solar cells), and $\mathrm{P}_{\mathrm{in}}$ is the intensity of the incident light.

The characteristic parameters for the DSSCs corresponding to Fig. 7 are summarized in Table 2. The DSSC fabricated on the bare FTO/glass electrode showed $\mathrm{V}_{\mathrm{oc}}$ of $0.6846 \mathrm{~V}_{\mathrm{sc}}$ of $4.0175 \mathrm{~mA} /$ $\mathrm{cm}^{2}$, FF of 75.9849 , and calculated power conversion efficiency of $\eta_{\text {AM1.5 }}=2.08 \%$. The DSSC deposited with $\mathrm{Nb}_{2} \mathrm{O}_{5}$ blocking layer showed maximum efficiency. As compared with standard DSSC, the conversion efficiency $(\eta)$, short circuit current $\left(J_{\mathrm{sc}}\right)$ of the DSSC with the $\mathrm{Nb}_{2} \mathrm{O}_{5}$ blocking layer were improved in $26.9 \%$ and $35.5 \%$ respectively. On the other hand, the open circuit voltage $\left(\mathrm{V}_{\mathrm{oc}}\right)$ was slightly diminished by $1.6 \%$. Another feature seen in this figure, the DSSCs with the $\mathrm{TiO}_{2}$ and $\mathrm{ZnO}$ blocking layers showed the also enhanced efficiency, $\eta(2.24 \%), \eta(2.64 \%)$ and short circuit current, $\mathrm{J}_{\mathrm{sc}}\left(4.2048 \mathrm{~mA} / \mathrm{cm}^{2}\right), \mathrm{J}_{\mathrm{sc}}\left(4.6245 \mathrm{~mA} / \mathrm{cm}^{2}\right) \mathrm{re}-$ spectively.

The reason for the enhancement of $\mathrm{J}_{\mathrm{sc}}$ with blocking layer is associated with the result of increase of protection effect against ionic penetration from electrolyte through the blocking layer. Consequently, the cell performance under illumination seems to indicate a decrease of the recombination rate in the cell when $\mathrm{TiO}_{2}, \mathrm{Nb}_{2} \mathrm{O}_{5}$ and $\mathrm{ZnO}$ were used as the blocking layer.

However, the DSSC with the $\mathrm{TiO}_{2}$ blocking layer showed lower efficiency than DSSCs with the $\mathrm{Nb}_{2} \mathrm{O}_{5}$ and $\mathrm{ZnO}$ blocking layer. The lower efficiency of DSSC with the $\mathrm{TiO}_{2}$ blocking layer possibly attributed to the fact of increment of the sheet resistance. As mentioned earlier, the sheet resistance value of $\mathrm{FTO} / \mathrm{TiO}_{2}$ electrode is more than twice larger than the sheet resistance values of $\mathrm{Nb}_{2} \mathrm{O}_{5}$ and $\mathrm{ZnO}$. For this reason, we considered that short circuit current, $\mathrm{J}_{\mathrm{sc}}$ was electronically lower than those of $\mathrm{Nb}_{2} \mathrm{O}_{5}$ and $\mathrm{ZnO}$. Also we might infer that $\mathrm{TiO}_{2}, \mathrm{Nb}_{2} \mathrm{O}_{5}$, and $\mathrm{ZnO}$ deposited on FTO electrodes were effectively reduce the electron recombination by minimizing the direct contact between the redox electrolyte and the conductive FTO surface.

\section{CONCLUSIONS}

In summary, the characteristics of the RF sputter grown various blocking layers $\left(\mathrm{TiO}_{2}, \mathrm{Nb}_{2} \mathrm{O}_{5}\right.$ and $\left.\mathrm{ZnO}\right)$ on the FTO electrode were investigated for the possible application of DSSCs. The DSSC deposited with $\mathrm{Nb}_{2} \mathrm{O}_{5}$ blocking layer, showed maximum efficiency. Compared with standard DSSC, the conversion efficiency $(\eta)$, short circuit current $\left(J_{s c}\right)$ of the DSSC with the $\mathrm{Nb}_{2} \mathrm{O}_{5}$ blocking layer were improved in $26.9 \%$ and $35.5 \%$ respectively. On the other hand, the open circuit voltage $\left(\mathrm{V}_{\text {oc }}\right)$ was slightly
Table 2. The fabrication of different blocking layers using RF magnetron sputtering method.

\begin{tabular}{ccccc}
\hline & $\mathrm{V}_{\text {oc }}(\mathrm{V})$ & $\mathrm{J}_{\text {sc }}\left(\mathrm{mA} / \mathrm{cm}^{2}\right)$ & $\mathrm{FF}$ & $\eta(\%)$ \\
\hline \hline Bare $\mathrm{FTO}$ & 0.68 & 4.01 & 75.98 & 2.08 \\
\hline $\mathrm{FTO} / \mathrm{TiO}_{2}$ & 0.69 & 3.09 & 76.27 & 1.64 \\
\hline $\mathrm{FTO} / \mathrm{Nb}_{2} \mathrm{O}_{5}$ & 0.67 & 5.44 & 71.96 & 2.64 \\
\hline $\mathrm{FTO} / \mathrm{ZnO}$ & 0.68 & 4.62 & 75.76 & 2.38 \\
\hline
\end{tabular}

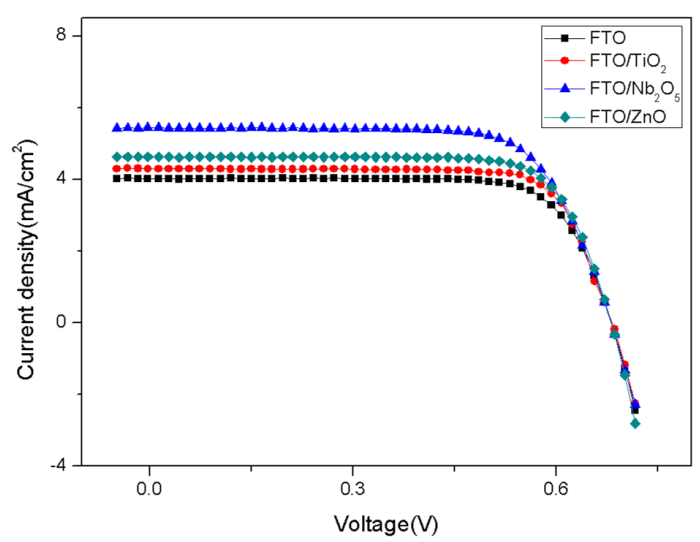

Fig. 7. Photocurrent-voltage curves with different types of blocking layer; (a) bare FTO electrode, (b) $\mathrm{TiO}_{2}$, (c) $\mathrm{Nb}_{2} \mathrm{O}_{5}$, and (d) $\mathrm{ZnO}$.

diminished by $1.6 \%$. Among the DSSCs with the blocking layers, the DSSCs with the $\mathrm{TiO}_{2}$ blocking layer showed lower efficiency than DSSCs with the $\mathrm{Nb}_{2} \mathrm{O}_{5}$ and $\mathrm{ZnO}$ blocking layers.

\section{ACKNOWLEDGMENT}

This work was supported by the research grant of Chungbuk National University in 2012.

\section{REFERENCES}

[1] B. O'Regan, M. Gräzel, Nature (London) 353 (1991) 737.

[2] M. Grätzel, Dye-sensitised solar cells: review, J. Photochem. Photobiol. C:

[3] A. F. Nogueria, C.L ongo, M.-A. Depaoli, Polymers in dye sensitized cells: overview and perspectives: review, Coord. Chem. Rev. 248 (2004) 1455-1468. D. L. Eaten, US Patent 3, 904422 (1975).

[4] B.A. Gregg, Interfacial processes in the dye-sensitized solar cell: review, Coord. Chem. Rev. 248 (2004) 1215-1224.

[5] M.F. Hossain, S. Biswas, T. Takahashi. Thin Solid Films 517 (2008) 1294-1300

[6] H. You, S. Zhang, H. Zhao, G. Will, P. Liu, Electochimica Acta 54 (2009) 1319-1324

[7] S. W, H. HAN, Q. Tai, J. Zhang, S. Xu, C. Zhou, Y. Yang, H. Hu, B. Chen, X.Z. Zhao, Journal of Power Souces 182 (2008) 119-123.

[8] J.R. Durrant, S.A. Haque, E. Palomares, Coord. Chem. Rev. 248 (2004) 1247.

[9] P. J. Cameron, L. M. Peter, J. Phys. Chem. B 107 (2003) 14394.

[10] K. Kalyanasundaram, M. Gratzel, Coord. Chem. Rev. 177 (1998) 347.

[11] E. Palmares, J. N. Clifford, S. A. Haque, T. Lutz, J.R. Durrant, Chem. Commun. (2002) 1464-1465.

[12] Z.-S. Wang, M. Yanagida, K. Sayama, H. Sugihara, Chem. Mater. 
18 (2006) 2912-2916.

[13] E. Palomares, J.N. Clifford, S.A. Haque, T. Lutz, J.R. Durrant, J. Am. Chem. Soc. 125 (2003) 475-482.

[14] P. J. Cameron, L. M. Peter, S. Hore, J. Phys. Chem. B 109 (2005) 930.

[15] S. Ito, P. Liska, P. Comte, R. Charvet, P. Pèhy, U. Bach, L. Schmidt-Mende, S. M. Zakeeruddin, A. Kay, M. K. Nazeeruddin, M. Gräzel, Chem. Commun. (2005) 4351.

[16] J. N. Hart, D. Menzies, Y.-B. Cheng, G. P. Simon, L. Spiccia, C. R. Chim. 9 (2006) 622.
[17] J. Xia, N. Masaki, K. Jiang, S. Yanagida, J. Phys. Chem. C 111 (2007) 8092.

[18] S.-J. Roh, R. S. Mane, S.-K. Min, W.-J. Lee, C. D. Lokhande, S.-H. Han, Appl. Phys. Lett. 89 (2006), 253512/1.

[19] Z.-S.Wang, M. Yanagida, K. Sayama, H. Sugihara, Chem. Mater. 18 (2006) 2912.

[20] X.Wu, L.Wang, F. Luo, B. Ma, C. Zhan, Y. Qiu, J. Phys. Chem. C 111 (2007) 8075.

[21] S.U. Lee, W.S. Choi, Byungyou Hong, Sol. Ener. Mater \& sol. Cel. 94 (2010) 680-685. 